\title{
Pentecostals and the pulpit: A case study of the Apostolic Faith Mission of South Africa
}

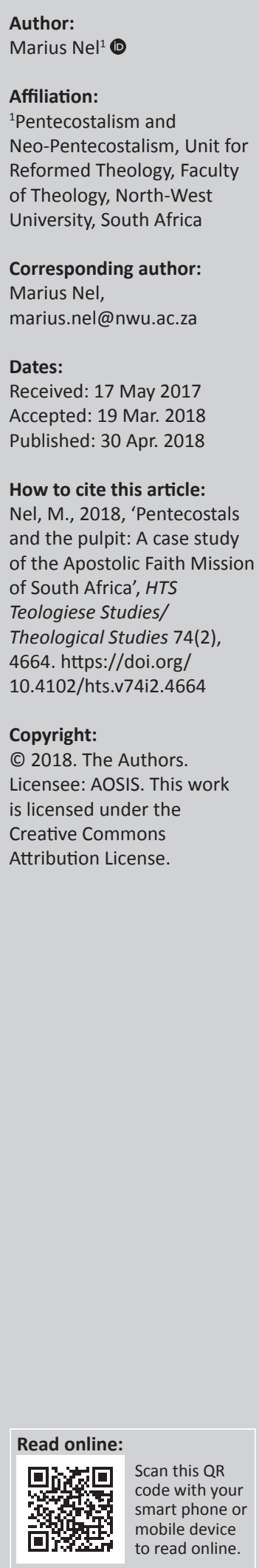

\section{Affiliation:}

${ }^{1}$ Pentecostalism and

Reformed Theology, Faculty

of Theology, North-West

, South Africa

\section{Marius Nel,}

Dates:

Received: 17 May 2017

Accepted: 19 Mar. 2018

How to cite this article:

Nel, M., 2018, 'Pentecostals

dhe pulpit: A case study

of South Africa', HTS

Teologiese Studies/

4664. https://doi.org/

$10.4102 /$ hts.v74i2.4664

Copyright:

C) 2018. The Authors.

Licensee: AOSIS. This work

is licensed under the
In general, early Pentecostals did not use any pulpits in their halls in order to underline their emphasis that each believer is a prophet and priest equipped by the Holy Spirit with gifts for the edification of other members of the assembly. All participated in the worship service by way of praying, prophesying, witnessing and bringing a message from God. From the 1940s, Pentecostals in their desire to be acceptable in their communities formed an alliance with evangelicals, accepted their hermeneutical viewpoint and built traditional churches in accordance with the Protestant tradition. From the 1980s, the pulpit started disappearing from the front of Pentecostal churches. This is explained in terms of new alliances that Pentecostals made with neo-Pentecostalist churches and a new hermeneutical viewpoint. The hypothesis of the article is that the Pentecostal stance towards the pulpit was determined by its hermeneutical perspectives. It is described by way of a comparative literature study and applied to a specific case study, the Apostolic Faith Mission of South Africa.

\section{Introduction}

Early Pentecostals did not utilise the term 'sermon'; it reminded them too much of the formalities associated with traditional Protestant churches. Rather than as a church, they viewed themselves as a movement established by the Spirit to spread the 'message' of Pentecost that Jesus wanted to baptise believers with his Spirit in the last days. There was an urgency in their calling because they expected the imminent second coming of Christ, adding eschatological fervour to their Pentecostal message of Spirit baptism (Macchia 2006:112). ${ }^{1}$ Because of the eschatological urgency of their task and in order to serve their anti-church feelings (see below), at first they did not hire or erect 'churches' in the traditional sense of the word; they used and later built halls that were multi-functional with chairs that could be moved around. It was important that furniture could be moved because these localities served various purposes, such as prayer meetings, worship services, youth and children meetings and business meetings of assemblies.

Their halls did not contain a pulpit where the professional pastorate ministered the sermon. They preferred to use the term 'message from the Lord', and anyone could participate in each aspect of the worship service, including bringing a message from the Lord (Olson 2004:88-89). The message could be in the form of a prophecy, that is, an ad hoc message perceived as to be received from the Spirit; a message brought through the speaking in tongues and interpreted by the one speaking in tongues or someone else who has received the gift of the interpretation of tongues; a premeditated message prepared beforehand and perceived to be a message God wants to bring to the congregation; or a word of encouragement or warning that someone wanted to bring ex tempore (Stronstad 1999:23-24).

There was also no professional pastorate; the assembly appointed those as leaders who had proved through their participation in the life of the people that they were anointed by the Spirit for different ministries. Assembly leaders took care that the worship service ran in an orderly fashion without in any way suppressing the free movement of the Spirit (Langerman 1983:124). At times, they brought a charismatic message but it was not their exclusive privilege; persons of any age, gender or literacy could be (and were) used by the Lord to bring such a message. In most worship services, there was more than one occasion for the ministering of the Word with several people participating in it. ${ }^{2}$

1.Pentecostals' gospel does not exclude Christ but rather sees the Spirit as the actualisation on the earth of the Christ who left the earth to sit at the right hand of the Father, in the same sense as Irenaeus who sees the Christ and the Spirit as the two hands of God (Land 2004:31). The Jesus event and the experience of the Spirit, Easter and Pentecost, form Christianity's two sources. They are intimately bound up in one another, but neither can absorb nor reduce the other (Comblin 1989:24). The tradition of Western Christianity lost its sense of the importance of the Spirit: there was one Easter, there are millions of Pentecostals.

2.White (1978:59) observes that God speaks his word to us through the mouths of other humans, a strange way to reach people. It displays a greater trust in humans than most of us would ever have, but it is God's way. He gives himself to us through those whom he has called to speak his word. If it was odd of God to choose the Jews, it was even odder to choose some of us, White contends. 
From the 1940s, this changed when the second generation of Pentecostals realised that the second coming of the Lord might perhaps not happen as imminently as expected (Chandomba 2007:15-17). The first generation had experienced rejection and social and economic discrimination to some extent; the second generation attempted to gain the acceptance of society and government in order to improve their position and counteract the discrimination. They made an alliance with evangelicals, leading in the US to the eventual establishment of the National Association of Evangelicals (NAE). Pentecostals struggled at first to cooperate with the evangelicals, but it was important enough for them to gain visibility and respectability among their evangelical peers, leaving behind their reputation as 'sectarians', that they cooperated with evangelicals. Their acceptance by and participation in the evangelical fray, however, came at a cost. To name a few instances, prior to the Second World War most Pentecostals were supporters of nonviolence. As pacifists, they would not participate in war and armed resistance, which involve the destruction of lives, in accordance with how they interpreted the Scriptures (Robeck 1988:635; 1997:136). The viewpoint was changed without much debate or opposition in accordance with the norms of Evangelicalism. Pentecostals' custom that women participated in all levels of ministry was also superseded by evangelical values that do not allow women (at that stage) to partake in the teaching ministry (Daniels 1999:235; Poloma 1989:119). The same happened to the custom that members participated in all aspects of the worship service; with the advent of a professional pastorate in accordance with the practices among evangelicals, the division between laity and professional pastorate was established among Pentecostals, with 'pastors' exclusively claiming certain functions such as the ministry of the Word for their office (Clark 2017:1). Pentecostals also accepted the evangelical viewpoint of verbal inerrancy and infallibility of Scriptures, aligning itself to a considerable extent with the fundamentalist use of the Bible (Anderson 1993:232). ${ }^{3}$

The Pentecostal movement now changed into a 'church' with church buildings that reflected other traditional Protestant churches, with a pulpit, pews and an organ, and even a church tower. This would only change again in the 1980s when, under the influence of neo-Pentecostalist churches, classical Pentecostals again changed their liturgy, including the institution of their liturgical space, in accordance with the successful independent (neo-Pentecostalist) macro assemblies. ${ }^{4}$ concerned with Pentecostals' claim that miracles and supernatural interventions still can and should happen in contemporary times (Kärkkäinen 1998:76-115) While fundamentalists and dispensationalists revered the appearance of miracles described in the Bible as one of the bedrock fundamentals of the faith, they limited direct supernatural intervention to a sub-dispensation of the church age in which the charismata and supernatural interventions occurred and which ceased when the canon of the New Testament was closed at the end of the apostolic era ('cessationist viewpoint'). Because Pentecostals tied the reappearance of the charismata to the restoration of the apostolic era, as a sign that the Latter Rain before the end of the age would herald the rapture of the church, they also expected that the phenomena of miracles that were associated with the apostolic era would continue in contemporary times.

4.The development in the 1990s of the church growth movement represents a different liturgical direction - one in which liturgy is seen as a barrier to seekers and is largely eliminated. At megachurches such as Willow Creek Community Church
A growing appreciation of symbolic representations of interaction with the divine has led to new arrangements of liturgical spaces and liturgical centres, much of this as the result of ecumenism (White 2002). At first, the pulpit was replaced by a catheder, preferably an acrylic, see through podium (Anderson 2011:1) and in some cases, it was removed in favour of a music stand or a round table.

These developments will be demonstrated at the hand of a case study to demonstrate the hermeneutical implications of these changes. However, it is necessary to provide a short historical overview of the utilisation of liturgical space in the Bible and Christian church.

\section{Pulpit in history}

Space is a powerful expression of the presence of the divine; sacred spaces imply a continuity of holiness (Pfatteicher 1997:142). ${ }^{5}$ God has always revealed himself to people in time and space. Inge (2005:33) shows that Genesis as the beginning of the Hebrew Bible already leaves the impression that place is important to the writer and God who took the initiative to create a space in the form of the Garden of Eden as a setting for the human beings, which would be created later. God placed man in this garden setting to maintain and keep it; paradise became a space where God regularly met with Adam and Eve (Duffield \& Van Cleave 1991:135). The presence of God with his people became the central focal point of Jewish and Christian faith. As Brueggemann (1994:679) argues, it is the presence of God in the midst of his people that made up of the Hebrew community an elected and special one. Place is a fundamental category of human experience, and consists of a threefold relationship between God, his people and place (Inge 2005:46). A proper biblical attitude to place will entail acknowledging that a relational view of it, inextricably bound up with both God and humanity, is essential.

At the heart of the covenant between Israel and God were the Ark of the Covenant and the Tent of Meeting that served as forerunners of the Jerusalem Temple. These objects signified the Lord's presence in the midst of his people (Nereparampil 1984:162). De Klerk (1999:171) shows that God's presence was confirmed by the celebration of different festivals that people held within the holy space of the temple and at home. These festivals celebrated God's work through history and his continual presence. God would indeed come to his people

\footnotetext{
to look as 'unchurchy' as possible in order to remove any barriers to evangelism Willow Creek, for example, could be mistaken for a nearby corporate headquarters. Participation is not a goal as the congregation relaxes in theatre seating. All that is required in this setting is a small portable lectern on the platform and room for actors and musicians (White 2002).

5.Brueggemann (1977) criticises the dominant categories of biblical theology that he identifies as the existentialist and mighty deeds of God in history, with either an exclusive concern with the urgent possibility of personal decision-making in which one chooses a faith context or the normative events around which Israel's faith has clustered. In the process, he outlines a new hermeneutic, where space and place are clustered. In the process, he outlines a new hermeneutic, where space and place are given room next to time, leading to a new interest in the theology of land and place. He encourages readers of the Bible to take a fresh look at place as a primary category of faith; land is a central, if not the central theme of biblical faith. Brueggeman (1977:11) also distinguishes between space as an area of freedom, without coercion or accountability, free of pressures and void of authority, and place as space which has historical meanings, where some things have happened which are now remembered and which provide continuity and identity across generations.
} 
in a particular way in space and time, not it a static way but on the move, wherever they were (Giles 2004:15). The Holy Spirit is God extending himself in active engagement with his creation in a personal way as the presence of God that completes God's contact with his creatures in every sphere (Berkhof 1994:98).

Liturgy is of a metaphorical design, because this is the only way we can speak to and about the invisible God (Vos 2003:180). ${ }^{6}$ These metaphors are intended to feed spirituality. Dawn (1995:71) contends that the deepest identity of liturgy is that God is the centre thereof. It was the presence of God in the midst of his people that led to the practice of liturgy in Israel (De Klerk 2000:461). Because of his presence, Israel developed liturgical acts such as prayer, song, feasts and offerings (Dawn 1995:71). Barnard $(1981: 61,67,86)$ demonstrates that the roots of the modernday worship service are found in the Old Testament where the nation regularly met to worship God in the temple and (post-exilic) synagogues. Paul and probably the other apostles continued to follow the model of the synagogue service in their Christian worship services (De Klerk 1999:173).

McGrath (1999:130) argues that Christian spirituality requires the structuring of spiritual geography. ${ }^{7}$ The only space or geography that is ultimately necessary is whether or not people worship 'in Jesus's Name'; architecture and buildings used for worship services quietly preach messages about God with every congregation's buildings providing their implicit understanding of God and his ways for them. McGrath (1999:130) then argues that it is important to take note of the way that architecture relates to spirituality because one clear function of religious architecture is to stress the transcendent presence of God that is immanent when the congregation meets. An important part of architecture is symbolism in the church that has been investigated for a long time (Greeff 2002:11) and that gives meaning to life (Phillips 2003:108). Religious symbols represent value systems with which people orientate themselves towards general society. Thiessen (2001:213) finds there is a growing consensus that the re-cultivation of aesthetics is needed, not only as theological addendum but also as locus theologicus. Cilliers (2003:8; 2004:2) adds that it is from the art of aesthetics that we can look theologically at the realities around us and reflect these in a responsible liturgical way in the worship service. The power of liturgy is that it can create an alternative world where time and space unfold in structured ways indicative of pattern, plan and purpose - despite the temptation to view the world as random, chaotic and accidental (Hoffmann 1988:155, 265).

6.According to Deist (1990:145), liturgy is the prescribed form and order of the acts to be performed at a public religious ceremony. Tomberlin (2010:34) defines the context of Pentecostal spirituality as a Christo-pneumatic ecclesiology where the values pursued are to encounter Christ and the Spirit in the course of the worship service. 7.Lathrop (1994:7) argues that the essentials of Christian worship are a community
gathered around word and sacrament. They are a participating community together with its ministers gathered on the Lord's Day in song and prayer around the scriptures, read and preached; around the baptismal washing, enacted or scriptures, read and preached; around the baptismal washing, enacted or
remembered; and around the holy supper. In terms of the liturgy, these elements form the spiritual geography.
Adams (1993:176) indicates that the goal of liturgical space is to create spaces that honour the sanctity of God's people and shape their experience of being church. ${ }^{8}$ Space in religious ritual action is sacred space that is to be distinguished from other spaces. According to White (1993:163), it is therefore necessary that the church should realise that there exists a correlation between faith and spaces. One characteristic of faith is that it gives meaning to the world or, in other words, to the time and space in which believers find themselves (cf. Buitendag 2002:940). A hermeneutics of spaces or variable liturgical spaces (Adams 1993:176) is needed to correctly guide the believer in their faith and daily living.

Until the 3rd century, the Christian church did not own any church buildings. Christians met in houses to minister to one another and worship God (Oostenbrink \& Lötter 1999:17). In time, several houses were bought or donated in which these communities held their meetings for spiritual activity (Cobb 1992:492). From the Pauline writings and Acts, it becomes clear that spirituality for these believers functioned within the community they shared with other believers (Eph. 4:16), and in created liturgical spaces like the temple (Ac 3:1). ${ }^{9}$

After 312 CE, the Christian church left their underground hiding places and private houses for public basilican churches. The church now rapidly grew in numbers and assets (Wepener 2003:195) and the bishops became public figures, invested with the dignity of magistrates (Wybrew 1992:486). Christian worship became a public performance and its ceremonies became correspondingly more elaborate (Wybrew 1992:486). Constantine built at his own expense churches in Rome, Jerusalem, Bethlehem and Constantinople as impressive and grand as the emperor's courts and palaces to serve as Christian places of worship (Pfatteicher 1997:150; Walker 1997:129). The churches were mostly built rectangularly on the model of the courthouses (Estep 1992:11) and the seat of the judge became the seat of the bishop. Preaching was difficult in these basilicas because of the size and no provision was made for a pulpit (Wegman 1985:94). De Kerk (1982:53) shows that with the development of the

8.Space, like speech, can be broken down into sentences and words. The first component of liturgical space is congregational space. This space is populated by bodies; Mackey (2006:26) emphasises the necessity for the whole person to become involved in the sacred experience of worship. Ideally, preaching should engage each congregant's five senses, inspiring the whole person (Mackey 2006:27). The second kind of space our churches contain is movement space Christian The second kinds conside worship demands considerable movement. White (1978:62) remarks that two things of major significance have happened in Christian worship since the 4th century. Somewhere around the 14th century, congregational space, which had been open fluid space for over 1000 years, became jammed with pews. The mobile congregation that ebbed and flowed throughout the nave, gathering wherever the action was, now settled for a congested parking lot. The unencumbered people place became an occupied territory, a furniture place stuffed full of pews. The other major change was that 16th-century Protestants, having already lost their legs, now lost their senses of smell, taste and touch and traded in Eucharistic worship for nonsacramental worship. Protestant worship became a head-trip.

9.The first reference to pulpitum is found in a letter of Cyprian, bishop of Carthage, in the mid-3rd century CE. Cyprian refers to ordination as it relates to the puliptum of his church building. This is probably the first reference of any sort to the formal development in the building or arrangement of churches. Pulpitum, however, does not refer to the later idea of a pulpit but to a slightly raised dais or platform at one not refer to the later idea of a pulpit but to a slightly raised dais or platform at one end of the assembly hall where the clergy sat. Cyprian explains that the honour of ordination is symbolised in ascending the pulpitum and standing conspicuously in front of the people on the higher plane. It seems that the phrase, 'to come to the pulpitum', is the technical term for the ordination of a reader in the church of Carthage (White 1990:23). This coincides with what is today called the platform in contemporary church buildings and there is no indication that it was used for preaching the Word (Anderson 2011:2) 
Roman liturgy, the altar gradually replaced the practice of reading of Scripture and accompanied preaching. Dargan and Turnbull (1974:88) describe how John Chrysostom variously sat in the ambo or on the steps of the altar as he preached his sermons. The ambo was a small desk used for the reading of the lessons and at times also for the preaching of sermons (Fiddes 1961:29). At first, it seemed that the ambo was placed in the front and centre of the sanctuary. Now a distance developed between the clergy and laity (Skarsaune 2002:431).

From the 8 th to the 12 th centuries, the predominant building style was the Roman style that reflected the castles and fortresses of the time. The churches were dark inside with mathematically ordered rooms with different chapels, altars and spaces instead of the one room that identified Constantinople's basilicas. The new style was directly linked to the new forms of liturgy that developed and the new spaces enhanced and accommodated these liturgies. The buildings were well suited for singing by choirs and other forms of the drama around the altar that characterised medieval Western liturgy, but were not good for preaching. The pulpit appears in a lateral (sometimes elevated) position of the cathedral (Fiddes 1961:30), representing the less prominent place of preaching and the heightened emphasis upon liturgical aspects of worship.

Between 1200 and 1400 CE, the Gothic style of architecture came into being with the emphasis on height, width and the entry of light. European society now experienced a regeneration and renewal of intellectual and cultural life (Volz 1997:118), accompanied by a theological awakening that coincided with a huge building programme of impressive and creative church structures (Pfatteicher 1997:150). Now church buildings were mostly cruciform, designed primarily for the celebration of mass, intended to be a visual reminder of the sacrifice of Christ and adorned with important portrait scenes from the Bible (Estep 1992:12). The pulpit became extremely ornate in its construction with carved stairways, intricate ornamentation and grand canopies (Bangs 1997:31-43).

The Reformation of the 16th century brought a renewed interest in spirituality and the space that contains it. Previously, the Church had huge, grand buildings but these had minimal spiritual value according to Protestant perceptions. The power of the Reformation came from Reformers preaching the living Word of God (Matheson 2000:124) and the values of the Reformation were also reflected in the architecture of church buildings. They were drastically altered in order to create room for the renewed sense of spirituality, with the centrality of preaching of the Word emphasised in the central position of the pulpit in the middle of the liturgical space (Estep 1992:155, 214, 245; Fiddes 1961:42-43). ${ }^{10}$ The altar transitioned to the pulpit, as

10.Stob (1962:6) is concerned that 'off-centre' pulpits that he notices in his day migh mean 'off-centre' notions about the Word and 'off-centre' practice in the preaching of the Word. He argues that there are no great issues involved in the placement of the preaching of the Word now gained priority over the mass at the altar (Estep 1992:155). Protestant churches were characterised by simplicity and only sacramental necessities were included like the bell, the pulpit, the baptismal font and the communion table. De Kerk (1982:53) shows that Protestants once again emphasised the priesthood of all believers as in the early church and the building was ordered in such a way that all believers could be close to the pulpit. The Reformers taught that the worship services should be simple with less elaborate ritual, in a language that the people understood and containing nothing that was contrary to Scripture or could not be justified by the Scripture. The new churches were one-roomed buildings of a size that enabled all present both to hear and see everything clearly (Cobb 1992:490).

By the 18th century, the church interior was dominated by the pulpit surrounded by pews (Cobb 1992:491). The 19th century was dominated by a Gothic revival in architecture, especially in Britain. Churches were built and restored according to an imagined medieval ideal. However, although the Gothic revival was responsible for a return of the basic two-roomed medieval arrangement, the chancel for the clergy was placed in the centre with room for a lay choir on both sides (Cobb 1992:492). The 20th century saw the development of the cell church concept, requiring multifunctional buildings with rooms for numerous activities, all around a bigger central space for general meetings of believers. This structure tries to give expression to the living plurality that coincides with the existing challenges of the believer's life (Ford 2003:285). Still, the pulpit assumes a central, though less ostentatious position, built more for functionality (Anderson 2011:2).

De Klerk (2000:452) claims that the contemporary Western world is experiencing an identity change brought about by a technological society that enhances secularism and the forming of a monoculture. This places extreme pressure on the liturgical activity of the Protestant church where room is needed for the sermon but also for a space where members of the congregation can get involved in meaningful relationships and where they can reach out in a caring way to others. Therefore, many churches have opted to do away with the highly elevated pulpits and replace it with functional communicative spaces, with ample room for movement, music, drama and multi-media presentations. They opt for a pulpit that is not a communication barrier but that will actually enhance the preaching (Kelderman 2005:3). This pulpit is not high and big, but close to the people and made in such a way that it is moveable and light. Pulpits are made from granite, acrylic, steel or wood with styles that suit every

\footnotetext{
the pulpit if it be considered merely a detail of church plan, nor even if it be considered from the point of view of the achievement of a greater measure of liturgical propriety or beauty. But if it touches the question of loyalty to convictions and confessions, and a due reverence for the Word of God and its preaching, this is surely something to which serious heed should be given. However, Stob (1962:8) contends that given Protestants' complete indifference to the symbolic, it is impossible to maintain that the central pulpit in the Christian Reformed Church is an important symbol of the conviction concerning the centrality of the Word and rather demonstrates that the Protestant approach to religion and worship is overwhelmingly and dominantly intellectual, without adequate concern for the full and total worship needs of the soul.
} 
taste and purpose. ${ }^{11}$ Contemporary audiences are little inclined to respect authority on the basis of position and they are not convinced by the trappings of authority. They will only commit to a preacher that attracts them relationally (Anderson 2011:3).

\section{Case study: The Apostolic Faith Mission of South Africa}

John G. Lake and Thomas Hezmalhalch started their ministry in South Africa in a hall in Doornfontein, Johannesburg, where a small multiracial Zionist assembly held their services after the larger group of people relocated to Bree Street in Johannesburg. The leader of the Zionist work, an American missionary called Daniel Bryant, had left for America. The first service was held on 25 May 1908 (Burger 1987:167). Before long, most Zionists in Johannesburg joined the Pentecostal work where several miracles were reported and eventually the Bree Street church board invited the two Americans to their church when the Doornfontein hall became too small to accommodate all the attendees (Burger \& Nel 2008:55). ${ }^{12}$ The early Apostolic Faith Mission (AFM) held evangelistic services in the open air where many people were converted, especially alcoholics who were rehabilitated. Ordinary members witnessed at these open-air services about their encounters with God and the way it influenced their lives and families, making it easy for listeners to identify with the speakers. In the worship services, members also participated by way of testimonies, messages, praying and items of singing or music, and leading interested people to conversion who responded to the evangelistic invitation (Chandomba 2007:26). The shared understanding was that anyone could partake at any time 'as led by the Spirit'.

Early assemblies apart from the Bree Street church held their services in houses, and eventually they hired and then bought halls. ${ }^{13}$ At their meetings in houses, an elder would lead the service or prayer meeting (Van Staden 1980:5). Again, all attendees participated by praying, witnessing and serving each other with a prophecy or message. Because of the discrimination, persecution, scorn and opposition of other established churches, especially the three so-called Sister (Reformed) churches, early Pentecostals formed an antichurch sentiment that led them to reject anything associated with traditional and established churches, as a reaction against the formality and rigidity of the historical churches (Burger 1987:181). ${ }^{14}$ In the hall, there was in many cases a

11.Anderson (2011:2) complains that it serves to complicate the contemporary confusion about the place of the pulpit.

12.For unknown reasons, the Pretoria Zionist assembly did not join the new movement.

13. Houses and halls served as the seat of relations and of meeting and activity between God and the world, in Inge's (2005:68) terms.

14.The AFM adopted its name in imitation of the name of the Azusa Street Mission What is important is that the AFM viewed itself as a movement rather than a church because 'church' reminded them of the traditional churches that they had left with what they perceived as its mustiness, rigidity, formality and its attachment to tradition, while 'Mission' reminded them of progress and movement. Another to tradition, while 'Mission' reminded them of progress and movement. Another
reason why the AFM wanted to be known as a Mission was its conviction that its missionary task to carry the message of Pentecost to the world was an urgent missionary task to carry the message of Pentecost to the world was an urgent eschatological task that required all its attention (Burger 1987:185-186). This led to the AFM registering itself only after five and a half years, and then not as a church but as a company. The early evangelists and missionaries (a historical apartheid table rather than a pulpit, signifying the democracy of participation by all members. ${ }^{15}$ The pulpit served as a symbol of authority and placed boundaries around the preaching of the Word (Anderson 2011:3) and for that reason, it was avoided. Pentecostals believed that the power is in the Word and not in the furniture (Anderson 2011:4). ${ }^{16}$ Anybody was welcome to explicate and teach the Scriptures where the main hermeneutical angle was that the only precondition for understanding and interpreting the Bible was the guidance of the same Spirit who had inspired the biblical authors (Menzies 2010:38-39). Any Spirit-filled Christian had all that was needed to understand what the Bible says because the method of interpretation was reflective reading in the context of prayer with a listening attitude. The believer then experienced that the Spirit enlivened a specific text to such an extent that its application for the current situation became clear, and this in many cases led the church member to share the 'revelation' with other members in the course of the worship service.

Because of the anti-church sentiment among early Pentecostals, they also held a dim view of all professional church leaders (Minutes of the General Annual Conference, 13 June 1919, Minutes book I: 300-301). In their desire to emulate the early church, Pentecostals organised their leadership along the lines of the New Testament with its concept of voluntary ministry by persons without any formalised theological training with all members of the body of Christ being involved (Langerman 1983:125). ${ }^{17}$ Everybody who complied with certain moral standards and were active on a part-time basis in ministry qualified to be called 'workers' and they received certificates acknowledging their ministry, either as 'evangelists' or 'missionaries'. Everybody was called 'brother' and 'sister' and nobody held an appointment (Burger 1987:181; Van der Spuy 1985:105-106). In the beginning, no one received any remuneration; fulltime workers were required to trust God for their sustenance (Editor, Comforter, November-December 1929:2). At times the AFM distributed money among the workers when it had received enough donations.

During the years of the Second World War, the AFM experienced a boom; equally striking is the gradual but clear

relic of the time when 'evangelists' preached to whites and 'missionaries' to blacks!) did not wish to put up a church but only an organisation that could serve their immediate needs. The company was organised along collegialist lines with 'Rules and Regulations' 'Rules and Regulations' accepted in October 1912 (Minutes of the Conference Business Meeting, 04 October 1912; Preliminary Minutes Book of the Executive Council). The AFM would only register as a church when a Private Bill of 1961 was
passed in the parliament (Burger 1987:212).

15.Democracy of participation implies that we project our voice and reach out our hands, whether it be hands that wash others, hands that give the Lord's body, hands that are laid on others' heads, hands that unite those of a couple, hands that bless or reconcile or hands that sprinkle a coffin. In each instance, God places himself in our hands so that he can give himself to others. And we have to be close enough to really touch them, writes White (1978:60).

16.This does not deny that the pulpit, font and table for communion are pieces of liturgical furniture that bear those elements in our midst, and that we perform the central actions of speaking and listening, washing and welcoming, eating and drinking and giving thanks (Wasserman 2007:16). How these spaces are used will also communicate their purpose and value (Wasserman 2007:17).

17.Land (2004:30) refers to the shift of the centre of Christianity from the United States and Europe (the North) to the majority world of the southern hemisphere, noting the pervasive Pentecostal character of these non-modern but discerningly critical Christians who are re-establishing the church as the body of Christ with its democratisation of ministries. 
changes that occurred now and in the decade after the close of the war, with changed attitudes towards the notion of being church (Putter 2010:1), with the AFM officially registering as a church in 1961; changes in church architecture from halls to traditional church buildings complete with pulpits, pews and organs; changes in offices with 'deacons' and 'elders' replacing the 'workers' and 'church boards' substituting 'local committees' or 'management boards' of earlier and changed attitudes towards established churches (Burger 1987:297-310). The AFM also changed its attitude towards society and social life to exchange its separation and exclusiveness for participation in the mainstream economic and political life. This eventually led to spiritual ablation with growth in membership falling to $5 \%$ and with $23 \%$ of AFM assemblies in 1953 not baptising a single person (Burger 1987:311). The reasons for the changes that marked the 1950s and 1960s can be found in the improvement of the socio-economic and educational situation of a new generation of AFM members, leading to changes in their values, outlook on life and social involvement and alignment. Now it became important for the AFM to shed its stereotype as a church for simple, poor and illiterate people, leading to the church's investment in proper theological training for its pastors (Nel \& Van Rensburg 2016:9). Burger (1987:297) ascribes these changes also to what he calls a historical truth that profound changes always occur after the passing away of the first generation of a new revival or renewal movement. The leaders of the movement with the vision in their hearts are no longer present and the enthusiasm and 'first love' of the second generation do not match those of the first generation.

Since the 1940s, it became important for the AFM to enjoy recognition in order to partake in religious broadcasts by the South African Broadcasting Company (SABC). The SABC did not respond to repeated requests by the church from 1944 until 1956, when the SABC required from the AFM their articles of faith. The Spiritual Committee of the AFM was tasked to draw up such a confession, and their proposal was based upon the Belgic Confession of Faith of 1561 (Burger 1987:296). Only in 1960 the SABC invited the AFM to partake in its broadcasts. In their quest to become acceptable, the AFM associated with evangelicals (Jacobsen 1999:93), a respected company (Kärkkäinen 1998:80). Now the AFM also established a Bible school to train pastors in the evangelicals' fundamentalist-literalistic way of reading the Bible (Lewis 2016:4; Nel \& Van Rensburg 2016:13). The AFM also eventually accepted the fundamentalist-dispensationalist hermeneutic of the evangelicals with their literalism and doctrine of the inerrancy of Scripture (Daniels 1999:247; Lewis 2016:5; Synan 1988:324-327). When Pentecostals started utilising fundamentalist evangelical textbooks, it had some unforeseen results, such as accepting the more formal liturgy in worship services and diminishing the historical role that women previously played in Pentecostal ministry (Daniels 1999:235; Poloma 1989:119, 241-243). ${ }^{18}$

18.Formerly, the Bible served as the main (and in many instances, the only) textbook (Nel \& Van Rensburg 2016:4)
Now the worship service in the church building with its pulpit was in the hands of the full-time 'professional' male pastor who was primarily responsible for the teaching and preaching ministry with members in the pews only participating in the worship of congregational singing and, when invited, to partake in prayers (Menzies 2013:129). All these changes within the AFM eventually led to unrest, breakdown and a schism with the originating of the Pentecostal Protestant Church on 10 October 1958. ${ }^{19}$

Since the 1970s, some AFM pastors qualified themselves theologically at different tertiary institutions (Lewis 2016:7). While they maintained a commitment to the reliability of Scripture, they eventually and eclectically adopted some of the methods of historical criticism (Fee 2002:3). However, this led to a growing divergence between Pentecostal pastors and members, and theologians (Cargal 1993:179; Lederle 1988:162; Lewis 2016:10), with most members and pastors reading the Bible in a more fundamentalist-literalist way as Pentecostals had been doing for the past seven or eight decades.

Simultaneously, a new trend was observed where the pulpit was replaced by a catheder and the area in front of the church building was changed to accommodate an orchestra and precentors, while house churches or cell groups were reinstituted to provide specialised pastoral care for individual members and with the declared intent to establish the church as the body of Christ..$^{20}$ The model of the body of Christ was utilised to organise the church. ${ }^{21}$ The reason for these changes can be found in the imitation of prominent pastors in the AFM of successful independent macro assemblies, most of neo-Pentecostalist orientation, such as Rhema Bible Church, Hatfield Christian Church and others as well as the new hermeneutical angle.

The hermeneutical angle developed by theologians in the ranks of classical Pentecostals shows striking agreements with early Pentecostal hermeneutics (cf. Nel 2014:291-309, 2015:1-21). In the early days, the Pentecostal movement was characterised by a charismatic, eschatologically flavoured spirituality that also lay at the heart of its reading of the Bible (Kärkkäinen 1998:77; Land 1993:3), informed by experiential observation rather than theological reflection. The Pentecostal community lived in and from the eschatological presence of God, and an encounter with the supernatural was emphasised (Archer 1996:64). Experience played a role in the beginning of

19.The story is told from an AFM perspective in Burger (1987:316-347) and Burger and Nel (2008:146-165)

20.The act of abandoning the traditional pulpit and standing without a large barrier before people is symbolic, argues Anderson (2011:3). The preacher offers a nonverbal affirmation of interest in and proximity to the people. In the post-Gutenberg era of orality (Ong 1982), a look-them-in-the-eye approach might just be the ticket, claims Fant (1987:165-168). A sermon can be just as effective in this television and image-dominated age as a literate pulpit style (Anderson 2011:3). White (1978:65), however, argues that if we really do believe that the reading and preaching of the word is a fresh theophany each time the people of God gather, then we ought to provide physical testimony to the visual aspects of that in the form of a pulpit that provide physical testimony to the visual aspects of that in the form of a pulpit that opinion.

21.White (2002) makes the important observation that congregational space should contribute to the understanding that we all are actors in the dramatic interaction of worship, not passive participants of a 'worship experience'. A commitment to of worship, not passive participants of a 'worship experience'. A commitment to
the primacy of the Word probably implies that pulpits should suggest the majesty of God's Word without being overpowering examples of authoritarianism. 
the hermeneutic process as presupposition and not only as verification (Stronstad 1992:18). Pentecostal hermeneutics was informed by a supernatural, charismatic ethos as well as an intense eschatological expectation (Archer 1996:65; 2009:71), when Spirit baptism was interpreted as introducing the decisive final steps to the consummation that would usher in the kingdom of God. Pentecostals perceived that they were living in the time of the latter rain (Cargal 1993:163; Synan 1971:146).

At the heart of classical Pentecostalism as represented by the new hermeneutics stands the Bible as the inspired Word of God, affirming that the (whole) Bible is a reliable revelation of God, and that it states the exact truths the Holy Spirit intends to convey (Arrington 1996:101). The starting point and foundation for Pentecostal faith and praxis is the biblical text, making the real issue in Pentecostalism hermeneutics, which is defined in Pentecostalism in terms of the role of the Spirit in realising the distinctive nature and function of Scripture in the faith community (Arrington 1996:107). Inerrancy of the Bible was not the basis in early or contemporary Pentecostal hermeneutics, but the Bible is perceived as inspired and preserved by the Spirit with the express purpose to illuminate, teach and transform the lives of contemporary believers. The Spirit who inspired and preserved the Scriptures illuminates, teaches, guides, convicts and transforms through that Word today, so that Scripture only becomes effective as Spirit-Word (Land 1993:94). In other words, the Bible becomes the Word because of the Spirit's ministry (Land 1993:100) and the Spirit's authority comes before the authority accorded to the Bible (Land 1993:106; Welker 1996:76). For that reason, Pentecostals do not make a sharp distinction - like evangelicals - between 'inspiration' of the original text and 'illumination' of the read text by the Spirit (Henry 1979:500).

The main elements of a Pentecostal hermeneutics can thus be described as the interrelationship between the Holy Spirit as the one animating Scriptures and empowering the believing community with the purpose that members be equipped for ministry and witness in culturally appropriate ways. The Holy Spirit is the one who realises the Christ-event in the present. The centre of the Christian message is Jesus Christ but what is critical is the personal awareness and experience of the indwelling of the Spirit who sets Jesus present in the daily life of the believer (Williams 2015:1), a process determined by the Spirit.

While Protestants emphasise orthodoxy (correctness in doctrine and confession as derived from Scripture), Pentecostals stress orthopraxy. They do not deny the importance of doctrine being founded on the Bible but they seek validation of doctrinal truth in dynamic activity in the Spirit. In their preaching, they do not primarily aim at communicating doctrinal truths but to minister to the spiritual, physical, psychological and social needs of the people assembled to meet the Word, Jesus Christ (Clark \& Lederle 1989:64-65). Archer (2009:160) comments concerning Pentecostals' life with the Bible: Pentecostals love their Bible and Biblical themes and stories saturate Pentecostal oral testimonies because they assimilate scriptural stories, verses and concepts into their interpretation of reality. The Bible speaks about God and claims to be his Word, a claim that results in Pentecostals' acknowledgement of the homiletical value of the Bible and the necessity of the Spirit's guidance in interpreting it. However, it is not doctrine or tradition that makes Pentecostalism what it is; it is the presence of God in and among his people 'in a manner which is readily evident to participator and bystander alike' (Clark \& Lederle 1989:65). Pentecostal experience of the Spirit is in Pentecostal hermeneutics the legitimate presupposition of biblical interpretation (Stronstad 1992:18). For this reason, the goal of studying Scripture is 'knowledge of (not simply about) God' (Autry 1993:42). The Bible does not per se present itself as the Word of God but what we read in the Bible is mentioning of or references to the Word of God (Möller 1991:91). Although the Word is God, the Bible is not God. The Bible is the written witness about the Word of God, a road sign indicating the way to God and containing everything needed by humans about God and his will (Möller 1991:93). As a result, Scriptures are viewed as the primal point of reference for encounter with God because ' $[t]$ o encounter the Scriptures is to encounter God' (Johns 1993:14) and the Holy Spirit is present among his people, the community of faith.

What distinguishes Pentecostal Bible reading from other traditions is not a different interpretive method but a distinct narrative that leads to a coherent and cohesive interpretive manner in which the Spirit plays the most important role and the community of faith and its story forms the influential hermeneutical filter as pre-understanding forming the condition for understanding. Clark (2013:3) argues that the Bible should be used to provide direction and boundaries to proclamation and experience, with 'text' and 'Spirit' providing balanced emphases. Pentecostals regard their narrative tradition as synonymous with the New Testament narratives of experiences with baptism in the Spirit, and this narrative tradition provides the context for their search for meaning when they read the Bible. In this way, an experiential narrative forms the hermeneutical framework for interpreting Scripture, as well as experiencing reality.

In this way, the contemporary academic hermeneutics developed by a growing segment of theologians contributed to a new democratisation of ministry, ${ }^{22}$ including the ministry of the Word, and leading to the formal pulpit being replaced by a more friendly communicative device such as a catheder where believers can again utilise the opportunity to testify to their encounter with Christ through his Word and bring the message which is on their heart by the anointing of the Spirit.

22. Murray (2003:16) makes the interesting observation that the culture of American Catholicism includes a tradition of denigrating the rhetorical skills of its clergy, serving as a kind of democratic levelling device, to bring the priest 'down' to the level of the people. 


\section{Synthesis}

It has been argued that early Pentecostals did not use any pulpits in the halls they utilised for their gatherings to underline their emphasis that each Spirit-filled Christian was responsible for edifying their fellow-believers by partaking in the worship service, including the ministry of the message of the Lord. Their hermeneutical angle allows for every believer to interpret the Scriptures through the Spirit in them as a result of the baptism with the Spirit. From the 1940s, Pentecostals allied with evangelicals in order to become respectable, accepted their hermeneutical viewpoint and built traditional churches in accordance with the Protestant tradition. The evangelical hermeneutical angle determined the way Pentecostals used the pulpit. From the 1980s, the pulpit started disappearing from the front of Pentecostal churches when Pentecostals allied with neo-Pentecostalist churches and formed a new hermeneutical viewpoint as a result of its own academic, and specifically hermeneutical, endeavours. In this way, its hermeneutics determined the praxis of the Pentecostal churches in terms of the liturgical use of the pulpit.

\section{Acknowledgements Competing interests}

The author declares that he has no financial or personal relationships which may have inappropriately influenced him in writing this article.

\section{References}

Adams, S.W., 1993, A medley of practical theology, Unisa, Pretoria.

Anderson, K.C., 2011, 'The place of the pulpit', Preaching, March, 1-4, viewed 17 May 2017, from http://www.preaching.org/the-place-of-the-pulpit/

Anderson, R.S., 1993, 'Fundamentalism', in A.E. McGrath (ed.), The Blackwell encyclopedia of modern Christian thought, pp. 229-233, Basil Blackwell, Oxford.

Archer, K.J., 1996, 'Pentecostal hermeneutics: Retrospect and prospect', Journal of Pentecostal Theology 8, 63-91. https://doi.org/10.1177/096673699600400806

Archer, K.J., 2009, A Pentecostal hermeneutic: Spirit, scripture and community, CPT, Cleveland, $\mathrm{OH}$.

Arrington, F.L., 1996, 'The use of the Bible by Pentecostals', PNEUMA: The Journal of the Society for Pentecostal Studies 16(1-2), 101-107.

Autry, A.C., 1993, 'Dimensions of hermeneutics in Pentecostal focus', Journal of Pentecostal Theology 1(3), 29-50. https://doi.org/10.1177/096673699300100302

Bangs, J.D., 1997, Church art and architecture in the Low Countries before 1566, Sixteenth Century Journal Publishers, Kirksville, MO. (Sixteenth Century Essays and Studies, 37).

Barnard, A.C., 1981, Die erediens, NG Kerkboekhandel, Pretoria.

Berkhof, L., 1994, Systematic theology, Banner of Truth Trust, Pennsylvania, PA.

Brueggemann, W., 1977, The land: Place as gift, promise and challenge in biblical faith, Fortress, Minneapolis, MN.

Brueggemann, W., 1994, The new interpreter's Bible, Abingdon, Nashville, TN.

Buitendag, J., 2002, 'Die dans van die Christen: Die genealogie van tyd en ruimte in ' $n$ postmoderne samelewing', Hervormde Teologiese Studies 58(3), 940-955. https://doi.org/10.4102/hts.v58i3.586

Burger, I., 1987, Geskiedenis van die Apostoliese Geloof Sending van Suid-Afrika 19081958, Evangelie, Braamfontein. (Published DD dissertation, University of Pretoria).

Burger, I. \& Nel, M., 2008, The fire falls in Africa: A history of the Apostolic Faith Mission of South Africa, Christian Art, Vereeniging.

Cargal, T., 1993, 'Beyond the fundamentalist-modernist controversy: Pentecostals and hermeneutics in a postmodern era', Pneuma 15(2), 163-187. https://doi. org/10.1163/157007493X00158

Chandomba, L., 2007, The history of the Apostolic Faith Mission and other Pentecostal Missions in South Africa, AuthorHouse, Keynes.

Cilliers, J.H., 2003, “....Meer as wat die oog kan sien...”: Kantaantekeninge oor die interseksie van kuns, liturgie en prediking', Praktiese Teologie in Suid-Afrika 18(1), 8-42.
Cilliers, J.H., 2004, 'Estetika as uitbeelding van die publieke kerk: Liturgie op soek na beelde (1)', Referaat gelewer by die Werkgemeenskap vir Praktiese Teologie in Suid-Afrika gehou, Pretoria, 14-16th Januarie 2004

Clark, M., 2013, 'Pentecostalism and philosophy of religion', Paper read at the Philosophy and Religious Practices Workshop, University of Wales, viewed 10 May 2017, from https://philosophyreligion.wordpress.com/2013/05/

Clark, M., 2017, 'Contemporary Pentecostal leadership: The Apostolic Faith Mission of South Africa as case study', Cyberjournal for Pentecostal-charismatic Research 16 viewed 29 April 2017, from file:///C:/Users/NWUUSER/Documents/GroupWise/ Artikels/Ander\%20se\%20artikels/M.Clark\%20AFM\%20Research.html

Clark, M.S. \& Lederle, H.I., 1989, What is distinctive about Pentecostal theology? University of South Africa, Pretoria. (Miscellanea Specialia 1, Unisa).

Cobb, P.G., 1992, 'The setting of the liturgy', in C. Jones (ed.), The study of liturgy, pp. 485-492, Oxford University Press, New York.

Comblin, J., 1989, The Holy Spirit and liberation, transl. P. Burns, Orbis, New York.

Daniels, D., 1999, 'Everyone bids you welcome: A multicultural approach to North American Pentecostalism', in M.W. Dempster, B.D. Klaus \& D. Petersen (eds.), Globalization of Pentecostalism, pp. 222-252, Regnum, Irvine, CA.

Dargan, E.C. \& Turnbull, R.G., 1974, A history of preaching, Baker, Grand Rapids, MI.

Dawn, M.J., 1995, Reaching out without dumpling down: A theology of worship for the turn-of-the-century culture, Eerdmans, Grand Rapids, MI.

Deist, F., 1990, A concise dictionary of theological and related terms, Van Schaik, Pretoria.

De Kerk, B.J., 1982, Liturgiese grondlyne, NG Kerk Uitgewers, Kaapstad.

De Klerk, B.J., 1999, 'Die Heilige Gees en die Skriflesing in die samekoms van die gemeente', In die Skriflig 33(2), 165-186. https://doi.org/10.4102/ids.v33i2.622

De Klerk, B.J., 2000, 'Liturgiese Identiteitsvorming as antwoord op die invloed van die verbruikerskultuur', In die Skriflig 34(4), 451-468. https://doi.org/10.4102/ids. v34i4.610

Duffield, G.P. \& Van Cleave, N.M., 1991, Foundations of Pentecostal theology, L.I.F.E. Bible College, Los Angeles, CA

Estep, W.R., 1992, Renaissance and reformation, Eerdmans, Grand Rapids, MI.

Fant, C.E., 1987, Preaching for today, rev. edn., Harper \& Row, San Francisco, CA.

Fee, G.D., 2002, New Testament exegesis: A handbook for students and pastors, 3rd edn., Westminster John Knox, Atlanta, GA.

Fiddes, V., 1961, The architectural requirements of Protestant worship, Ryerson, Toronto.

Ford, D.F., 2003, 'Holy Spirit and Christian spirituality', in K.J. Vanhoozer (ed.), The Cambridge companion to postmodern theology, pp. 269-290, Cambridge The Cambridge companion
University Press, New York.

Giles, R., 2004, Re-pitching the tent, Canterbury, Norwich.

Greeff, M., 2002, 'Ja, vir nuwe simbole in die kerk?: Fokus', Die Kerkbode 168(3), 11.

Henry, C.F., 1979, God, revelation, and authority: God who speaks and shows, Word, Waco.

Hoffmann, L.A., 1988, The art of public prayer: Not for clergy only, Patora, Washington, DC.

Inge, J., 2005, A Christian theology of place, Ashgate, Hampshire.

Jacobsen, D., 1999, 'Knowing the doctrines of the Pentecostals: The scholastic theology of the Assemblies of God, 1930-55', in E. Blumhofer, R. Spittler \& G. Wacker (eds.), Pentecostal currents in American Protestantism, pp. 90-107, University of Illinois Press, Urbana, IL.

Johns, C.B., 1993, Pentecostal formation: A pedagogy among the suppressed, Sheffield Academic Press, Sheffield. (JPTSup, 2).

Kärkkäinen, V.-M., 1998, 'Pentecostal hermeneutics in the making: On the way from fundamentalism to postmodernism', Journal of the European Theological Association 18, 76-115. https://doi.org/10.1179/jep.1998.18.1.006

Kelderman, D., 2005, 'Embracing tensions: The story of how the seminary chapel renovation project became an occasion for Christian formation', Forum 12(2), 3-4. Land, S., 2004, 'The whole church is Pentecostal!', Living Pulpit 13(2), 30-31.

Land, S.J., 1993, Pentecostal spirituality: A passion for the kingdom, CPT, Cleveland, OH.

Langerman, J.L., 1983, 'Apostolic Faith Mission of South Africa: A revitalization of the theological concepts of church ministry', Unpublished DMin dissertation, Fuller Theological Seminary.

Lathrop, G.W., 1994, What are the essentials of Christian worship, vol. 1, Augsburg, Minneapolis, MN. (Open Questions in Worship).

Lederle, H., 1988, Treasures old and new: Interpretation of the Spirit baptism in the charismatic renewal movement, Hendrickson, Peabody, MA.

Lewis, P.W., 2016, 'Reflections of a hundred years of Pentecostal theology', Cyberjournal for Pentecostal-charismatic research, Paper presented at the 9th Annual Willieam Menzies Lectureship in January, 2001 at Asia Pacific Theological Seminary in Baguio, Philippines, pp. 1-25, viewed 31 January 2017, from http:// www.pctii.org/cyberj/cyberj12/lewis.htm\#_ftn1

Macchia, F.D., 2006, 'The kingdom and the power', in M. Welker (ed.), The work of the Spirit: Pneumatology and Pentecostalism, pp. 101-119, William B. Eerdmans, Grand Rapids, MI.

Mackey, J.A., 2006, 'Sensing God: The human body as a vehicle of worship', Living Pulpit 15(2), 26-27.

Matheson, P., 2000, The imaginative world of the Reformation, T\&T Clark, Edinburgh. 
McGrath, A.E., 1999, Christian spirituality, Blackwell, Oxford.

Menzies, W., 2010, The language of the Spirit: Interpreting and translating charismatic terms, CPT, Cleveland, $\mathrm{OH}$.

Menzies, R.P., 2013, Pentecost: This story is our story, GPH, Springfield.

Möller, F.P., 1991, Woord van lig en lewe: Deel 1: 'n Pinkster dogmatiese studie, AGS Drukkers, Westdene.

Murray, P.E., 2003, 'The ministry of the Word amid screaming amps and infants', The Living Pulpit 12(3), 16-17.

Nel, M., 2014, 'A critical evaluation of theological distinctives of Pentecostal theology', Studia Historiae Ecclesiasticae XL(1), 291-309.

Nel, M., 2015, 'Attempting to define a Pentecostal hermeneutics', Scriptura 114, 1-21. https://doi.org/10.7833/114-0-1044

Nel, M. \&. Van Rensburg, F., 2016, 'Integrating spirituality and rationality the long and arduous journey of the historical development of theological training in the Apostolic Faith Mission of South Africa', In die Skriflig 50(2), a1943. https://doi. org/10.4102/ids.v50i2.1943

Nereparampil, L., 1984, 'Biblical symbolism of the temple', Journal of Dharma 9, 161-174.

Olson, R.E., 2004, The Westminster handbook to evangelical theology, Westville John Knox, Louisville, KY. (The Westminster Handbooks to Christian Theology).

Ong, W.J., 1982, Orality and literacy: The technologizing of the Word, Routledge, London.

Oostenbrink, J. \& Lötter, G., 1999, Die groot God by klein groepe, DPM, Potchefstroom. Pfatteicher, P.H., 1997, Liturgical spirituality, Trinity, Pennsylvania, PA.

Phillips, A.P., 2003, 'Die rol van simbole in die vorming van die etos van die Christelike geloofsgemeenskap', Praktiese Teologie in Suid-Afrika 18(2), 100-115.

Poloma, M.M., 1989, The Assemblies of God at the crossroads, University of Tennessee Press, Knoxville, TN

Putter, A.P.J., 2010, 'Riglyne vir voortgesette teologiese opleiding: Uitdagings vir die AGS-kerk', Verbum et Ecclesia 31(1), Art. \#417, 1-8. https://doi.org/10.4102/ ve.v31i1.417

Robeck, C.M., 1988, 'National Association of Evangelicals', in S.M. Burgess \& G.B. McGee (eds.), Dictionary of Pentecostal and charismatic movements, pp. 634-636, Zondervan, Grand Rapids, MI.

Robeck, C.M., 1997, 'The Assemblies of God and ecumenical cooperation: 1920-65' in W. Ma \& R. Menzies (eds.), Pentecostalism in context, pp. 107-150, Sheffield Academic Press, Sheffield. (JPT Supp. 11)

Skarsaune, O., 2002, In the shadow of the temple, InterVarsity, Downers Grove, IL.

Stob, G., 1962, 'Where shall we place the pulpit?', Reformed Journal, March, 5-9.

Stronstad, R., 1992, 'Pentecostal experience and hermeneutics', Paraclete 26(1), $18-25$
Stronstad, R., 1999, The prophethood of all believers: A study in Luke's charismatic theology, CPT, Cleveland, $\mathrm{OH}$.

Synan, V., 1971, The Holiness-Pentecostal movement in the United States, Eerdmans, Grand Rapids, MI.

Synan, V., 1988, 'Fundamentalism', in S.M. Burgess \& G.B. McGee (eds.), Dictionary of Pentecostal and charismatic movements, pp. 324-327, Zondervan, Grand Rapids, MI.

Thiessen, G.E., 2001, 'Exploring a locus theologicus: Sacramental presence in modern art and its hermeneutical implications for theology', in E.L. Boeve \& J.C. Ries (eds.), The presence of transcendence, pp. 213-222, Peeters, Leuven.

Tomberlin, D., 2010, Pentecostal sacraments: Encountering God at the altar, CPT, Cleveland, $\mathrm{OH}$.

Van der Spuy, M.A., 1985, 'Die spanning tussen vryheid en formalisering ten opsigte van die liturgiese verskuiwinge binne die Apostoliese Geloof Sending van Suid-Afrika', unpublished MTh dissertation, University of South Africa.

Van Staden, A.J., 1980, Die Apostoliese Geloof Sending van Suid-Afrika: Hulle leer getoets aan die Skrif, HAUM, Kaapstad.

Volz, C.A., 1997, The medieval Church: From the dawn of the Middle Ages to the eve of the Reformation, Abingdon, Nashville, TN.

Vos, C.J.A., 2003, 'Liturgical language as metaphorical language', Praktiese Teologie in Suid-Afrika 18(2), 179-193.

Walker, W., 1997, A history of the Christian Church, T\&T Clark, Edinburgh.

Wasserman, M.A., 2007, 'Leading from font, table, and pulpit', Call to Worship: Liturgy, Music, Preaching \& the Arts 40(4), 15-24.

Wegman, H., 1985, Christian worship in East and West, Pueblo, New York.

Welker, M., 1996, 'Word and spirit, spirit and word: A Protestant response', Concilium 3, 52-79.

Wepener, C., 2003, 'Liturgie en versoening voor die Reformasie: 312-600 AD', Praktiese Teologie in Suid-Afrika 18(2), 194-210.

White, J.F., 1978, 'Liturgy and the language of space', Worship 52(1), 57-66.

White, J.F., 1993, 'Liturgical space forms faith', in M. Hestenes (ed.), A medley of practical theology, pp. 163-164, Unisa, Pretoria.

White, J.F., 2002, 'Rearranging the furniture: The changing face of worship space', Reformed Worship 64, viewed 17 May 2017, from http://www.reformedworship. org/article/june-2002/rearranging-furniture-changing-face-worship-space

White, L.M., 1990, Social origins of Christian architecture: Texts and monuments for the Christian domus ecclesiae in its environment, vol. II, Trinity Press International, the Christian domus ecclesiae in its environ
London. (Harvard Theological Studies, 42).

Williams, J.R., 2015, The Pentecostal reality, viewed 10 May 2017, from http://www. cbn.com/spirituallife/biblestudyandtheology/drwilliams/bk-pentacostalch03. aspx

Wybrew, H., 1992, 'The setting of the liturgy', in C. Jones (ed.), The study of liturgy, pp. 485-492, Oxford University Press, New York. 